\title{
British Gurkha Recruitment : A Historical Perspective
}

\author{
Kamal Raj Singh Rathaur *
}

The earliest Anglo - Nepalese relations can be traced back to the mideighteenth century, when British ascendancy was established in Bengal and Nepal was in the process of political unification. Since that time British objective was to open Nepal for the Europeans, where as Nepalese policy of exclusion and expulsion of British remained unchanged for nearly a century. Between 1767 and 1816, British interest in Nepal was to safeguard and foster the customary trade between Bengal and Tibet through Nepal. The means adopted by the British to achieve their object were military intervention to forestall the Gurkha conquest of the Nepal valley, the dispatch of various commercial missions to Kathmandu and the attempts at establishing British influence in the court of Nepal. None of these measures proved successful. Its result being only to sow in the Nepalese Durbar the feelings of deep distrust and hostility towards the British which lay at the root of Nepal's policy of exclusion and expulsion of the British.

By 1814, Nepal's territorial and military expansion had become the major threat to the Company's territories. At that time, promotion of trade with Nepal and Tibet become a background object where as the security of the frontiers of British India became the paramount concern of the East India Company.

The Anglo - Gurkha war (1814 - 1816) and the Treaty of Sugauli aimed at putting a definite limit to this expansion and restraining the Gurkha military power. During this war the British who were very much impressed by the bravery and brilliant fighting qualities of Gurkha, desired to augment their military power by enlisting them in their service. They also wanted to weaken the military power of Nepal by enlisting her brave fighting men into their own ranks.

Though they had started the recruitment of Gurkha during the war they declared the formation of four separate Gurkhas battalions namely, first Nasiri, Second Nasiri, Sirmoor and Kumaon battalions in 1815. By the time the war ended in the west in 1815, about 4,650 Gurkha soldiers were enlisted in the British Indian army. Each of the Gurkha battalion was to consist of 8 companies and 120 persons in each company. ${ }^{1}$ In 1826 the second Nasiri battalion was observed by the first one and altogether three Gurkha battalions came into existence out of the original four. During the thirty years period between 1816 and 1846 no definite arrangement was made for the Gurkha recruitment in British Indian army. No more Gurkha battalions could be raised. British military authorities had to adopt indirect means, sometimes smuggling of Gurkha recruits required for the then existing Gurkha battalions. Nepal Durbar did not show her co-operation in this regard;

Kamal Raj Singh Rathaur is an Associate Professor in the Central Department of History, Tribhuvan University, Kirtipur, Kathmandu, Nepal.

1. John Peamble, The Invasion of Nepal, London: Oxford Clarendon Press, 1971, p. 348. 
hence no progress in this field could be seen during this period. The three Gurkha battalions continued their existence.

The period between 1846 and 1885 can be regarded as the period of positive discouragement in the history of the recruitment of the Gurkhas into the British Indian army. During this period Jang Bahadur Rana and his immediate successor Ranauddip Singh discouraged the Nepalese subjects from joining the British ranks by introducing many restrictive measures. During this period two more Gurkha battalions were raised, one in 1857 and another in 1858. But during this period too no definite arrangement was made for the Gurkha recruitment. The requirement of the Gurkha recruits was fulfilled by an indirect way that is by enlisting the Nepalese without the prior knowledge and permission of the government of Nepal.

The year 1885 marks the turning point in the history of Gurkha recruitment. Bir Shamsher after his succession to the Prime Ministership of Nepal abandoned the traditional Nepalese policy of adopting stiff attitude towards the British. The period between 1885 and 1901 can be termed as the period of friendly co-operation with regard to the question of Gurkha recruitment. By adopting different measures, he made the recruiting process more and more easier. He gave permission to open Gurkha recruiting depots in India near the Nepalese borders. He himself took initiative in collecting the recruits for British government. In the year 1886 two more Gurkha regiments were raised, ${ }^{2}$ and additional second Gurkha battalions were raised in the previous five Gurkha battalions.

Between 1886 and 1892 altogether 7, 662 Gurkha recruits, mostly Magars and Gurungs, were supplied. ${ }^{3}$ In 1894 another Gurkha battalion was raised which in 1901 became the ninth Gurkha Rifles. ${ }^{4}$ In the same way, in 1895 first Burma Gurkha Rifles was raised which in 1901 , became the $10^{\text {th }}$ Gurkha Rifles. ${ }^{5}$ During the period between 1885 and 1901 besides the original five Gurkha regiments, four more Gurkha battalions were also raised.

Emergence of Chandra Shamsher as the Prime Minister of Nepal further improved the recruiting process. He did not put much obstructions on recruiting. ${ }^{6}$ Chandra Shamsher gave the British government every possible facility for the recruitment of Gurkhas. In 1902 another Gurkha regiment was raised. ${ }^{7}$ By 1908 the Gurkha brigade had reached its permanent establishment of 20 battalions organized

2. J.B.R. Nicholson, The Gurkha Rifles, Britain: Osprey Publishing Ltd. Berkshire, 1974, p.23.

3. Eden Vansittart, Gurkha, Handbook for the Indian army, Calcutta: Superintendent Government Printing, 1906. pp. 174-75.

4. Nicholson, f. n. no. 2, pp. 23-24.

5. Ibid., p. 24.

6. Asad Husain, British India's Relations with the Kingdom of Nepal (1857-1947), London: George Allen and Unwin Ltd., 1970, p.250.

7. Nicholson, f. n. no. 2, p.23. 
into 10 Rifle regiments. ${ }^{8}$ In 1914 there were some 26,000 Gurkhas serving in the ten regular Rifle regiments. ${ }^{9}$ During the World War I, Chandra Shamsher took every possible step to help British in the recruitment of Gurkhas. He also offered the regular Nepalese troops and Gurkha recruits to British. As a result during World War I, total number of men taken out of Nepal was 200,000. ${ }^{10}$ Out of 200,000, 55,000 men were enlisted in the regular Gurkha battalions of the Indian army. ${ }^{11}$

Gurkha recruitment went on satisfactorily between the two World Wars. The war clouds had already surrounded the European horizon by October 1938. As soon as the War became a threat to Britain, Maharaja Juddha Shamsher offered a Nepalese contingent of 8,000 troops for garrison duty in India. This offer was accepted a year later when War was actually declared. The British government also asked for Gurkhas to serve overseas, which Juddha Shamsher readily granted. Permission was also given to enlist additional Gurkha for garrisons, police duties and volunteer battalion of paratroopers. Juddha Shamsher like his predecessors left no stone unturned to please the British authorities by supplying adequate number of recruits. In all, some 160,000 Gurkha recruits reported to the different recruiting centers. ${ }^{12}$ Furthermore, in early 1940 Maharaja Juddha Shamsher sent eight battalions of the Nepalese army, commanded by two of his sons, to India, mostly destined for service on the frontier as before to release regular troops.

In the middle of 1940s, British government sought permission to recruit 7000 Gurkhas for six new battalions during the recruiting season of 1940-1941. This figure however did not include these 3500 recruits required annually to maintain the existing Gurkha regiments. ${ }^{13}$

Maharaja Juddha Shamsher readily granted permission. When the first batch of the recruits were just reporting at the recruiting depots, the British government made another urgent demand by asking permission to raise ten more Gurkha battalions by April 1941. ${ }^{14}$ Juddha Shamsher gave his approval to new proposals also. During the recruiting season of 1940, altogether 15,000 Gurkhas were recruited. ${ }^{15}$ In order to supply required number of recruits to the British government, Juddha Shamsher even stopped all recruitments for the Nepalese army. During these years, the recruitment had been so heavy that almost all the able-bodied young men had left the country and Nepalese Prime Minister delighted

8. Sushila Tyagi, Indo-Nepalese Relations (1858-1914), Delhi: D. K. Publishing House, 1974, p.211.

9. David Bolt, Gurkhas, London: Weidenfeld and Nicholson, 1967, p. 90.

10. Ibid., p. 90.

11. Tyagi, f. n. no. 8, p. 212.

12. Bolt, f. n. no. 9, p. 98.

13. Letters from Betham to the Maharaja Juddha, June 15, 1940, Foreign Ministry of Nepal, Poka No.560.

14. Ibid., September 15, 1940.

15. Ibid. 
by the magnitude of his success in supplying the recruits wrote to the Indian Commander-in-Chief, A.P. Wavell:

Bent on putting up what help we can offer to our great friend and ally in time of need my sole endeavor have remained directed to see the demand of recruits to the Indian army in full. It is a matter of gratification that the endeavor has proved successful. For a small hill country like ours, the supply of 65,000 recruits in the course of last three years is certainly a notable achievement. ${ }^{16}$

The supply of 65,000 recruits was only possible by opening new areas for recruitment, which had been hitherto prohibited. The target for Gurkha recruitment for the year 1944 - 1945 was 12,000. Maharaja Juddha Shamsher who cautioned the British authorities about the quality of the recruits due to the heavy recruitment, left no stone unturned to meet the target. ${ }^{17}$ All the ten regiments of the Gurkha brigade doubled their strength by raising third and fourth battalion whereas $1^{\text {st }}, 2^{\text {nd }}$ and $9^{\text {th }}$ Gurkhas raised fifth battalion also. In 1943, special battalions were formed as training battalions to give recruits realistic experience of combat and two Gurkha garrison units were also added. It has been estimated that by the end of the second World War, the Gurkhas serving with the British Indian army was equivalent of some 55 battalions. ${ }^{18}$ The cost of death-toll of Gurkhas alone was estimated to more than 10,000 men.

The Gurkha recruitment, which initially started with smuggling of recruits, reached to an anti-climax in 1945 when Indian Commander-in -Chief proposed to reduce the number. In a letter to the Nepalese Prime Minister Juddha Shamsher, he wrote:

It is with greatest pleasure that I am now able to inform Your Highness that, as a result of further detailed examination of the manpower situation I am in a position to reduce my demand for Gurkha recruits for the year 1945-1946 to 2,000 only. This will be ample to maintain existing Gurkha Rifle regiments at full strength. $^{19}$

With the end of the war, all the war-raised Gurkha battalions were disbanded. The proposal for the Indian independence in the post-War era necessitated the reorganization of the Gurkha regiments. For this, a tripartite agreement was concluded in August 1947 between the British, the Indian and the Nepalese government. This agreement confirmed that four of the Gurkha regiments

\footnotetext{
16. Letters from Maharaja Juddha to General A. P. Wavell, Commander-in-Chief of India, February 25, 1943, Foreign Ministry of Nepal, File No. 17.

17. $\quad$ Ibid., September 21, 1944, File No. 42.

18. Christopher Chant, Gurkha, England: Blandford Press, 1985, p. 101.

19. Letters from General Sir Claude Auchinleck to Maharaja Juddha Shumshere, June 30,1945, Foreign Ministry of Nepal.
} 
would go to the British army and that the other six would remain part of the Indian army. It was also agreed that the Gurkha regiments should not be used against Nepal, other Gurkhas and Hindus or unarmed mobs. The eight battalions of the $2^{\text {nd }}$, $6^{\text {th }}, 7^{\text {th }}$ and $10^{\text {th }}$ Gurkha Rifles which under the British army, formed the new brigade of Gurkhas left India for their new destination in Malaya at the beginning of $1948 .{ }^{20}$ But the recruitment for these battalions was agreed to be done in recruiting depots in India. When the Indian government imposed ban on recruitment on Indian soil, the British government, therefore, entered into an agreement with Nepal in July 1953. This agreement, which permitted the British to open recruiting depots at Dharan and Paklihawa, was subject to renewal every five years. In 1958, this agreement was extended for another ten years. ${ }^{21}$

The brigade of Gurkhas was made self-reliant by the addition of separate units of Gurkha Engineers, Gurkha Signals and Gurkha Transport Regiment. The status of the infantry regiments was also enhanced when $6^{\text {th }}$ Gurkhas became the $6^{\text {th }}$ Queen Elizabeth's Own Gurkha Rifles, the $7^{\text {th }}$ Gurkha became the $7^{\text {th }}$ Duke of Edinburgh's Own Gurkha Rifles and $10^{\text {th }}$ Gurkhas became the $10^{\text {th }}$ Princess Mary's Own Gurkha Rifles. ${ }^{22}$ The British policy of gradual withdrawal from the Far East resulted in the reduction of the strength of the Gurkha regiments. The shrinking of the brigade of Gurkha, which started in 1963, ended only in 1971 when the conservative government in England halted the rundown of the Gurkhas. By this time, there remained only five battalions of Gurkha with a total strength of 7000 men. The $2^{\text {nd }}$ Gurkhas was the only two-battalion regiment. In 1975 another cut was ordered by which the Gurkhas were to be reduced to 6,000 men by 1979. But in 1982, the brigade of Gurkha was ordered to be augmented and $2^{\text {nd }}$ battalion was added to the $7^{\text {th }}$ Gurkhas. ${ }^{23}$

The Gurkha under the British flag saw actions in Malaya, the Indonesian confrontation, troubles in Borneo and Brunei, the Cypriot War, Britain's War with Argentina in 1982 for the Falkland Islands and during the recent Iraq War.

The British government on June 4,1991 announced its decision to cut down army strength by 25 percent. With this, the speculations were made that the entire brigade of Gurkha will be disbanded. This news came as a shock not only to the families and relatives of those Gurkhas who were serving under the British flag, but also to those aspirant Nepalese youths who were planning to join that army.

After much speculation and guess work, the British government finally announced its decision on the brigade of Gurkhas. The brigade will stay but the number will be reduced from 8,000 men to strength of 2500 men only.

20. Chant, f. n. no. 18, p.146.

21. Grishma Bahadur Devkota, Nepal Ko Rajnaitik Darpan, Kathmandu: Dhruba Bahadur Devkota, 2036 B.S., p-171.

22. Chant, f. n. no. 18., p. 151.

23. Byron Farwell, The Gurkhas, Great Britain: Penguin Books, 1985, p. 277. 
The system of Gurkha recruitment has generated hot discussions on the very concept of allowing the country's youths to join the foreign armies. The critics argue that regular and unhindered recruitment by the British and Indian armies is stripping Nepal of some of its brightest young men, whose talents might be used in building up the homeland. They argue that the Nepalese youths in foreign armies fighting the wars against the countries, which has no enmity with Nepal, is not a right thing. They point out that the Gurkha units in the Indian army have fought against China and Pakistan and they were sent to Sri Lanka as part of an Indian peace keeping force, although Nepal does not want to antagonize any of those countries. The involvement of Gurkha troops in the 1982 Falklands war also had raised some controversy in the diplomatic circles. According to them, this practice is not only against the national prestige of Nepal but also a potential source of diplomatic embarrassment. Export of mercenaries as they say, must be stopped immediately.

On the other hand the supporters of continued recruitment assert that if all the soldiers are brought home a serious problem of unemployment is inevitable. Moreover, Nepal was getting nearly 47 million dollars annually as foreign exchange from British Gurkha as salary, remittances and pensions, and Indian currency worth 100 million dollars from those in the Indian army. There is no doubt that the economic aspect of Gurkha recruitment not only provides the nation with valuable foreign exchange but also serves as the lifeline for many Nepalese hill tribes for whom, joining foreign army is the major way out to make a better living for themselves and their families. 